Proc. Instruments, Methods \& Missions for the Investigation of Extraterrestrial Organisms

SPIE, International Soc. for Optical Engineering

San Diego, CA

July $27-$ August 1,1997

\title{
LABORATORY AND FIELD EVIDENCE FOR LONG-TERM STARVATION SURVIVAL OF MICROORGANISMS IN SUBSURFACE TERRESTRIAL ENVIRONMENTS
}

T. L. Kieft ${ }^{1}$, E. M. Murphy' ${ }^{2}$, P. S. Amy ${ }^{3}$, D. L. Haldeman ${ }^{3}$, D. B. Ringelberg ${ }^{4}$, and D. C. White ${ }^{5,6}$
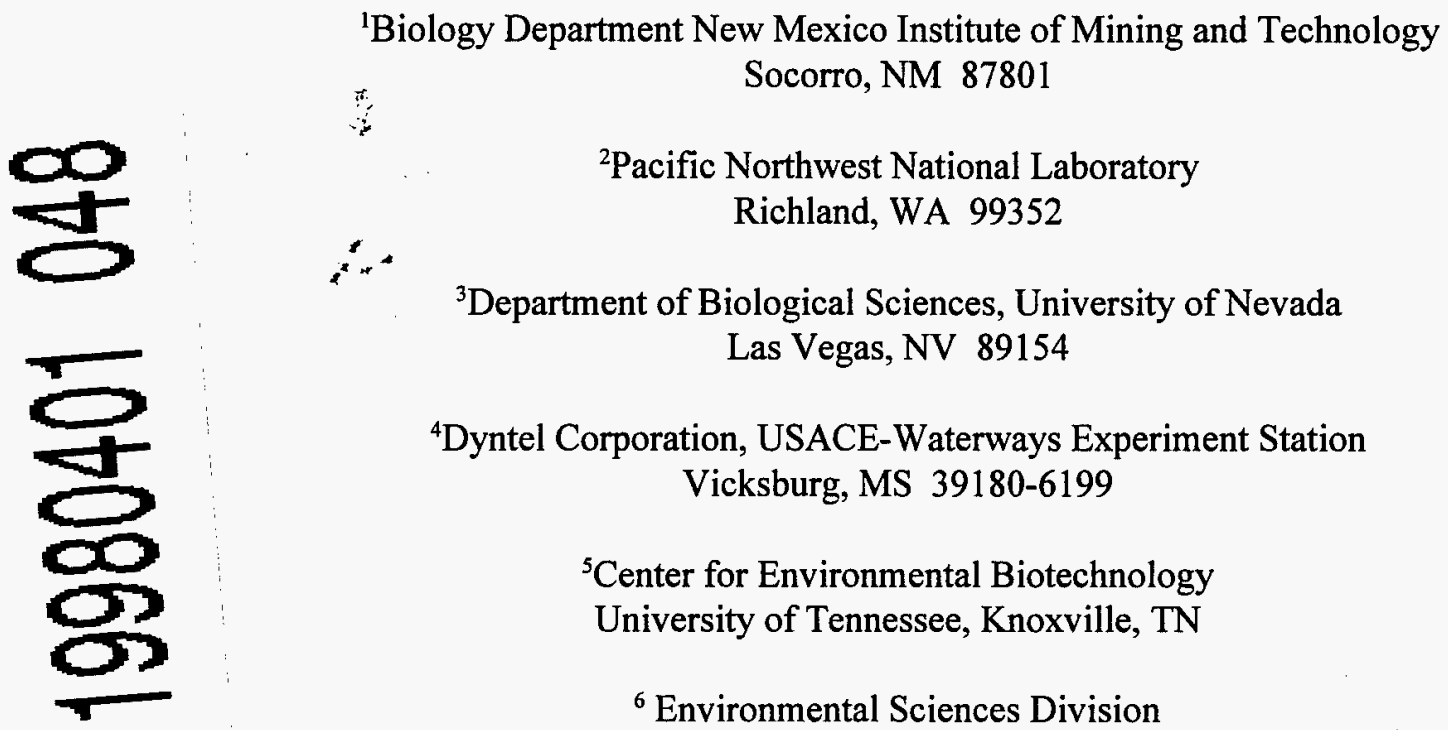

${ }^{6}$ Environmental Sciences Division

Oak Ridge National Laboratory*, Oak Ridge, TN

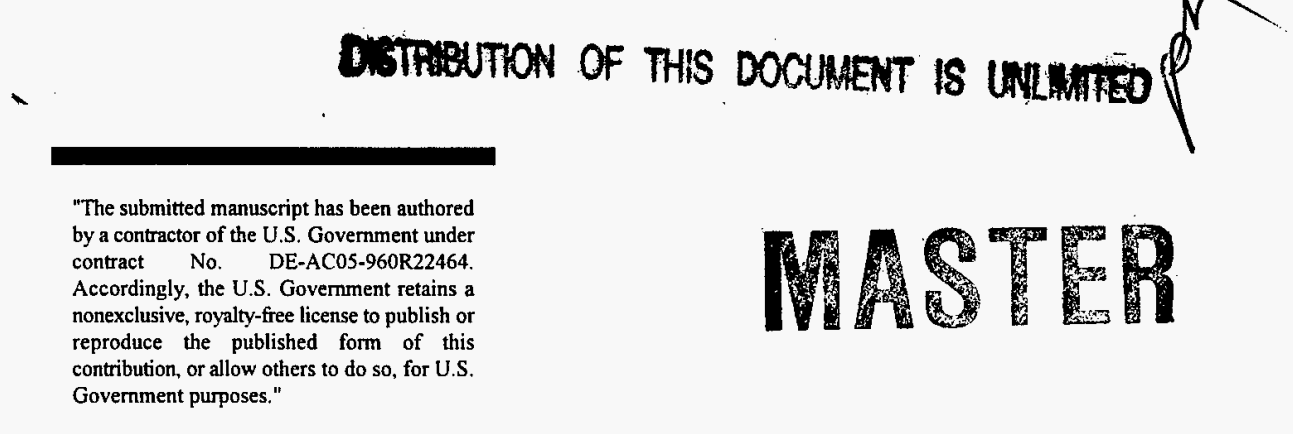

*Oak Ridge National Laboratory is managed by Lockheed Martin Energy Research Corp., for the U. S. Department of Energy under contract DE-AC05-960R22464. 


\section{DISCLAIMER}

This report was prepared as an account of work sponsored by an agency of the United States Government. Neither the United States Government nor any agency thereof, nor any of their employees, makes any warranty, express or implied, or assumes any legal liability or responsibility for the accuracy, completeness, or usefulness of any information, apparatus, product, or process disclosed, or represents that its use would not infringe privately owned rights. Reference herein to any specific commercial product, process, or service by trade name, trademark, manufacturer, or otherwise does not necessarily constitute or imply its endorsement, recommendation, or favoring by the United States Government or any agency thereof. The views and opinions of authors expressed herein do not necessarily state or reflect those of the United States Government or any agency thereof. 


\title{
Laboratory and field evidence for long-term starvation survival of microorganisms in subsurface terrestrial environments
}

\author{
T. L. Kieft ${ }^{a}$, E. M. Merphy ${ }^{\text {b }}$, P. S. Amy ${ }^{\text {c }}$ D. L. Haldeman ${ }^{\text {c }}$, D. B. Ringelberg ${ }^{\text {d }}$, and D. C. White \\ aBiology Department, New Mexico Institute of Mining and Technology, Socorro, NM 87801 \\ ${ }^{b}$ Pacific Northwest National Laboratories, Richland, WA 99352 \\ ${ }^{c}$ Department of Biological Sciences, University of Nevada, Las Vegas, Las Vegas, NV 89154 \\ dDyntel Corporation, USACE-Waterways Experiment Station, Vicksburg, MS 39180-6199 \\ ${ }^{e}$ Center for Environmental Biotechnology, University of Tennessee, Knoxville, TN 37932
}

\begin{abstract}
Biogeochemical modelíng of groundwater flow and nutrient flux in subsurface environments indicates that inhabitant microorganisms experience severe nutrient limitation. Using laboratory and field methods, we have been testing starvation survival in subsurface microorganisms. In microcosm experiments, we have shown that strains of two commonly isolated subsurface genera, Arthrobacter and Pseudomonas, are able to maintain viability in low-nutrient, natural subsurface sediments for over one year. The'se non-spore-forming bacteria undergo rapid initial miniaturization followed by a stabilization of cell size. Membrane lipid phospholipid fatty acid (PLFA) profiles of the Pseudomonas are consistent with adaptation to nutrient stress; Arthrobacter apparently responds to nutrient deprivation without altering membrane PLFAs. To test survivability of microorganisms over a geologic time scale, we characterized microbial communities in a sequence of unsaturated sediments ranging in age from modern to $>780,000$ years. Sediments were relatively uniform silts in eastern Washington State. Porewater ages at depth (measured by the chloride mass-balance approach) were as old as 3,600 years. Microbial abundance, biomass, and activities (measured by direct counts, culture counts, total PLFAs, and radiorespirometry) declined with sediment age. The pattern is consistent with laboratory microcosm studies of microbial survival: rapid short-term change followed by long-term survival of a proportion of cells. Even the oldest sediments evinced a small but viable microbial community. Microbial survival appeared to be a function of sediment age. Porewater age appeared to influence the makeup of surviving communities, as indicated by PLFA profiles. Sites with different porewater recharge rates and patterns of Pleistocene flooding had different communities. These and other studies provide evidence that microorganisms can survive nutrient limitation for geologic time periods.
\end{abstract}

Keywords: microorganisms, subsurface, starvation, survival, phospholipid fatty acid biomarkers

\section{INTRODUCTION}

It is now well established that the biosphere extends far beneath the earth's surface, to depths of at least $3 \mathrm{~km}$ at some

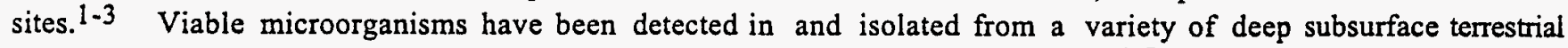
environments, including saturated and unsaturated (vadose zone) rocks and sediments). ${ }^{4-7}$ Many of these deep subsurface environments impose extreme conditions with regard to temperature, pressure, and nutrient availabilities. Energy sources, particularly various forms of organic carbon, are generally in short supply. Dissolved organic carbon concentrations in subsurface porewaters are usually quite low, typically less than $1 \mathrm{mg} \mathrm{L}^{-1} .8$ Solid phase organic carbon may be present and comprise $1 \%$ or more by weight of subsurface sediments; however, much of this carbon is refractory to microbial degradation and may also be relatively inaccessible to microorganisms. Bacteria may be immobile and unable to access organic carbon sources due to small pore throat diameters in low permeability rocks and sediments and due to thin, discontinuous water films in unsaturated environments, $6,7,9$ or their metabolism may be limited by availability of electron acceptors or other inorganic nutrients. ${ }^{10}$ These low nutrient concentrations, combined with generally low groundwater flow rates, result in extremely low nutrient flux. Low nutrient flux, in turn, constrains inhabitant microorganisms to glacially slow rates of metabolic activity and concomitantly long generation times. ${ }^{11-13}$ Phelps et al. estimated generation times of hundreds to 
thousands of years for microorganisms in deep subsurface sediments. Rather than actively growing, the majority of subsurface bacteria appear to be surviving in a starved, relatively inactive state. 12

The existence of microorganisms in the subsurface can be the result of recent transport into the subsurface, long-term survival of microorganisms that were deposited at the time of geologic deposition, or a combination of these two processes. ${ }^{8}$ Given the very low groundwaterflow rates in most subsurface rocks and sediments, transport of colonizing bacteria into the subsurface is slow. Coastal plain aquifer sediments of the southeastern United States present an example of groundwater flow that is fast relative to most other groundwater environments, yet the groundwater ages within the aquifers where microbial communities have been detected are as old as 11,000 years. ${ }^{8}$ Thus, survival of existing populations is at least as important as immigration of new populations in these environments. In many subsurface environments, microorganisms appear to have been starving in situ for thousands to millions of years. In some cases, the subsurface microbial communities appear to be derived directly from populations of bacteria that were deposited at the same time as geologic deposition and burial of subsurface material. Examples of ancient communities of this type include those in thick unsaturated zones with low recharge rates ${ }^{4}$ and deep saturated environments with extremely tight formations. 10,14

The traditional approach to studying starvation survival is to grow environmental isolates in the laboratory, resuspend them in a non-nutrient solution, and then to quantify the decline in numbers of cells with time. ${ }^{15}$ The physiological state of the starved cells can then be determined by quantifying cellular constituents, e.g., nucleic acids, proteins, storage products, phospholipid fatty acids (PLFAs), etc. Unfortunately, this approach is limited by the length of time that one can incubate starved cells, the limit generally being a single funding period. The physiological state of bacteria starved for one $t \rho$ two years may or may not resemble the condition of bacteria that have starved in situ for geologic time periods. Another ápproach to studying starvation survival is to attempt to recover viable bacteria from ancient materials that have been protected from outside contamination for periods ranging from decades to millions of years. ${ }^{16}$ The current record for recovery of bacteria sealed for the longest time in situ is 25 million years for a Bacillus sp. isolated from the gut of an insect preserved in amber. ${ }^{17}$ The unfortunate drawback to this approach is that the extremely low numbers of surviving cells in these materials precludes any assessment of their physiological state and once they have been revived in culture, their status has been radically altered. At best, one can determine the size of such ancient bacteria using light or electron microscopy, but the small size and low numbers can make this task especially difficult.

Miniaturization of bacterial cells to form dwarf cells (also known as ultramicrobacteria, nanobacteria, or volumetrically challenged bacteria) is a common response to starvation conditions. 18 Deprived of external nutrient sources, bacteria survive by endogenous metabolism, i.e., breakdown of storage compounds and other cellular macromolecules. The energy provided by endogenous metabolism fuels the reactions necessary for maintenance of cell viability, e.g., cellular repair mechanisms, including DNA repair. Miniaturization of bacterial cells is tied to this endogenous metabolism. Diminished size also increases the surface-to-volume ratio, thereby increasing the capacity for uptake of nutrients relative to the cell mass to be maintained. Bacteria observed within subsurface sediment and rock matrices are typically relatively small, $\leq 0.5 \mu \mathrm{m}$ in diameter. This is further indication of the starvation conditions that exist in the subsurface and the physiological stress of subsurface bacteria.

Several questions come to mind when one considers surviving communities of ancient subsurface bacteria. For instance, one can ask whether subsurface bacteria are even more highly adapted for starvation survival than surface bacteria. If subsurface bacteria are truly able to survive adverse subsurface conditions for geologic time periods, one would like to know more of the physiological state of these cells. The majority of microorganisms that have been isolated from subsurface environments are non-spore-formers, and so most appear to be surviving as vegetative cells. What characteristics enable these cells to maintain cellular integrity practically indefinitely without nutrient input? Long-term survival in the subsurface is likely a function of physical and chemical conditions as well as properties of the microorganisms themselves. Identification of properties that favor long-term persistence of microbial communities would enhance our understanding of the subsurface. Properties that may enhance survival include residual organic carbon, moisture saturation, and clay minerals. One can also ask which populations within a microbial community are best adapted for long-term survival in situ and which populations disappear.

This paper describes our recent efforts to characterize the status of subsurface bacterial cells undergoing long-term starvation survival and to determine the environmental factors that influence long-term survival. Both laboratory and field sampling approaches were used. Laboratory microcosm studies were used to compare the starvation survival capabilities of surface and subsurface bacteria. Field studies were used to determine the community makeup and physiological status of microorganisms that have been sequestered in situ for time periods ranging up to one million years. 


\subsection{LABORATORY MICROCOSM APPROACH}

Subsurface bacterial isolates have been tested in laboratory incubations for their abilities to survive conditions of little or no nutrients. ${ }^{19-21}$ Amy et al.'s study of several bacteria isolated from deep subsurface volcanic tuffat the Nevada Test Site showed that the isolates were able to survive in a non-nutrient artificial porewatermedium for 100 days and that the bacteria miniaturized during the incubation period. ${ }^{19}$ Overall patterns of starvation survival and morphological change were very similar to those observed in marine and freshwater isolates. We have carried out short-and long-term starvation experiments in porous media on strains of Pseudomonas and Arthrobacter. ${ }^{20-21}$ The genera Pseudomonas and Arthrobacter are frequently isolated in culture from diverse subsurface environments. In microcosms composed of silica sand as a model porous medium, it was shown that a subsurface Pseudomonas strain that was deprived of nutrients altered its membrane lipid PLFA profiles in patterns that were very similar to those of starved aquatic bacteria. ${ }^{20}$ Similar treatment of an Arthrobacter strain resulted in no discernible change in membrane lipids. ${ }^{20}$

More recently, we have tested the starvation responses of subsurface Pseudomonas and Arthrobacter isolates and have compared them to those of closely related strains isolated from surface environments. ${ }^{21}$ The close phylogenetic relationship between the two Pseudomonas isolates and between the two Arthrobacter isolates was demonstrated by similarity in 16S IRNA sequences. The microcosms were designed to mimic in situ conditions more closely than in previous experiments. Two differentsubsurface sediments were used as porous media. One was a fluvial silt deposit and the other was a similar silt that underwent soil development prior to burial. Previous studies have shown that unsaturated buried soils (paleosols) typically have higher numbers of microorganisms than nearby sediments that never underwent soil development. 4,6 The higher numbers in the paleosols may reflect large populations that existed in the soil before burial. Another possibility is that the physical/chemical conditions of buried soils favor microbial survival. Because moisture is thought to play an important role in microbial survival in the subsurface, ${ }^{6}$ the effects of moisture were also tested in these microcosms. Saturated and unsaturated moisture conditions were imposed in separate treatments. Microcosms were incubated for over 1 year. During that time, microcosms were sacrificed at various time intervals and the microorganisms within were tested for total cell numbers, numbers of culturable cells, and cell sizes.

All strains of bacteria survived reasonably well in the microcosms. Greater than $99.9 \%$ of cells remained culturable after over one year of incubation. In fact, culturable cells declined by less than 3 orders of magnitude from the initial levels of approximately $10^{8}$ cells $\mathrm{g}^{-1}$ in over 1 year of incubation. Rates of decline in the total numbers of cells and the numbers of culturable cells did not differ significantly between subsurface and surface strains, either for the Pseudomonas strains or for the Arthrobacter strains (Fig. 1). These data refuted our original hypothesis that subsurface strains of bacteria are better adapted than surface strains to long-term survival. However, our one year incubations may have been too short for differences in survivorship to appear between strains. Both arthrobacters survived better than either pseudomonad. This is not surprising given the well known starvation survival abilities of Arthrobacter spp. in soils. ${ }^{22}$ If one extrapolates the exponential survival curves of these bacteria, it appears that none would remain culturable in the microcosms after only a few years, far less than the geologic time period that was hypothesized. However, loss of culturability does not necessarily mean loss of viability. The cells may be entering a viable but non-culturable state, as is common for a very large proportion of subsurface bacteria in situ. Also, exponential curve-fitting may not accurately describe survival of these bacteria over the long term. Instead, populations of viable cells may level out at population densities typically observed in the field.

Environmental parameters exerted a strong effect on microbial survival. Survival was generally greater in the paleosol than in the non-paleosol silt sediment. All strains of bacteria survived better under saturated conditions than under unsaturated conditions. These findings are consistent with observations of microbial abundance in natural subsurface sediments: saturated sediments tend to have higher biomasses than vadose zone sediments, ${ }^{6,7}$ and paleosols often have higher microbial biomasses than other sediments. ${ }^{4,6}$

All strains of bacteria miniaturized during long-term incubations (Fig. 2). No significant differences in cell sizes occurred between surface and subsurface strains of the same genus. The Arthrobacter strains decreased in size rapidly during the first 24 hours, losing approximately $90 \%$ of their volumes; thereafter, the rate of miniaturization slowed considerably. The Pseudomonas strains gradually diminished in size over the first four weeks and thereafter slowed their rates of miniaturization. Microcosm conditions appeared to have little influence on the rates of miniaturization. There was no significant difference in cell volumes of bacteria as a result of differences in sediment types or moisture contents. Although all strains tested underwent a miniaturization response, they did not reach the diminutive cell volumes of true dwarf cells (Kieft, in press), within the timeframe of these experiments. It may be that by slowing their rates of endogenous metabolism and thus slowing their rates of miniaturization, these cells are able to maintain viability in situ for millennia. 

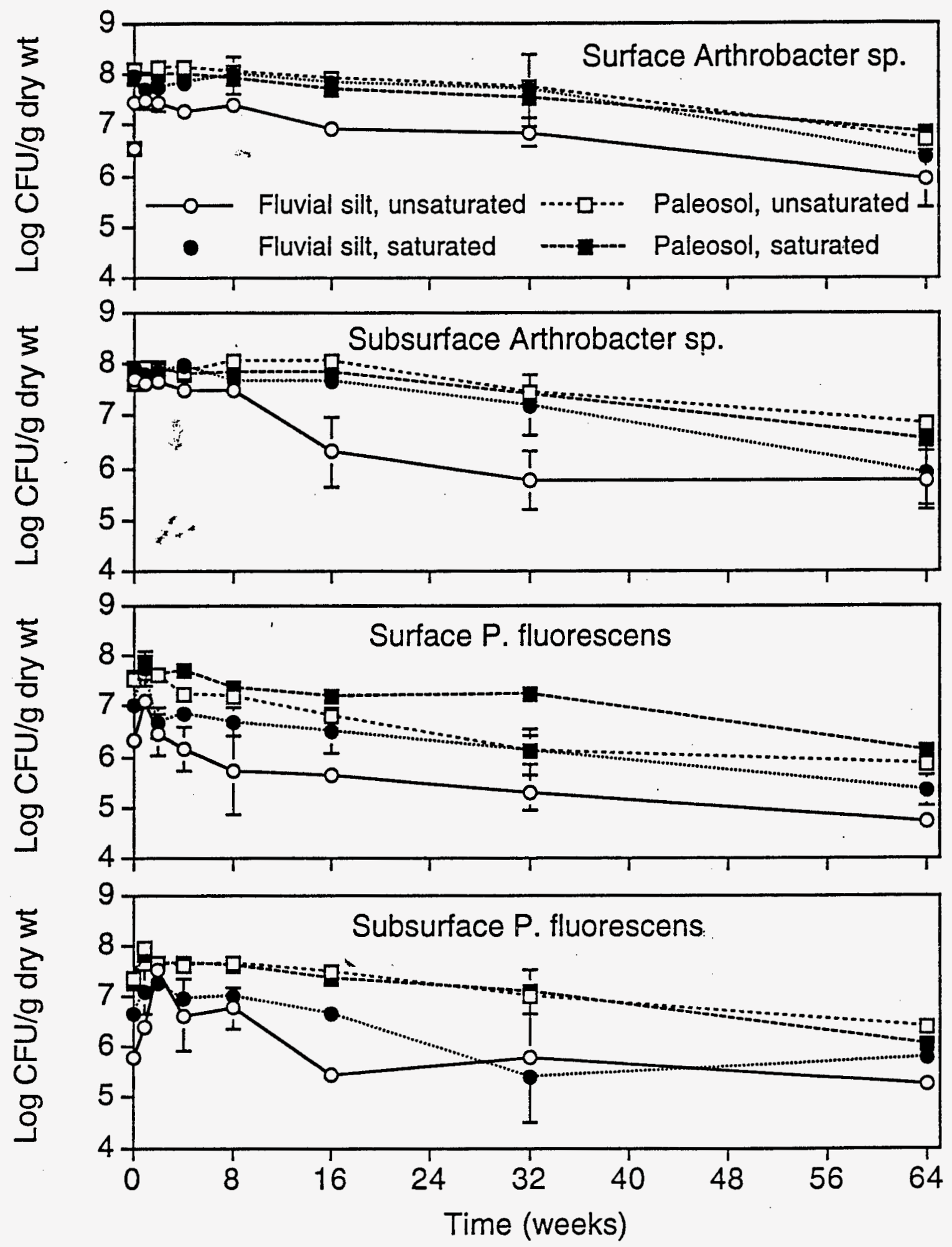

Figure 1. Plate counts of surface and subsurface bacterial strains incubated in sediment microcosms. Error bars show one standard deviation. (from reference 21, with permission). 

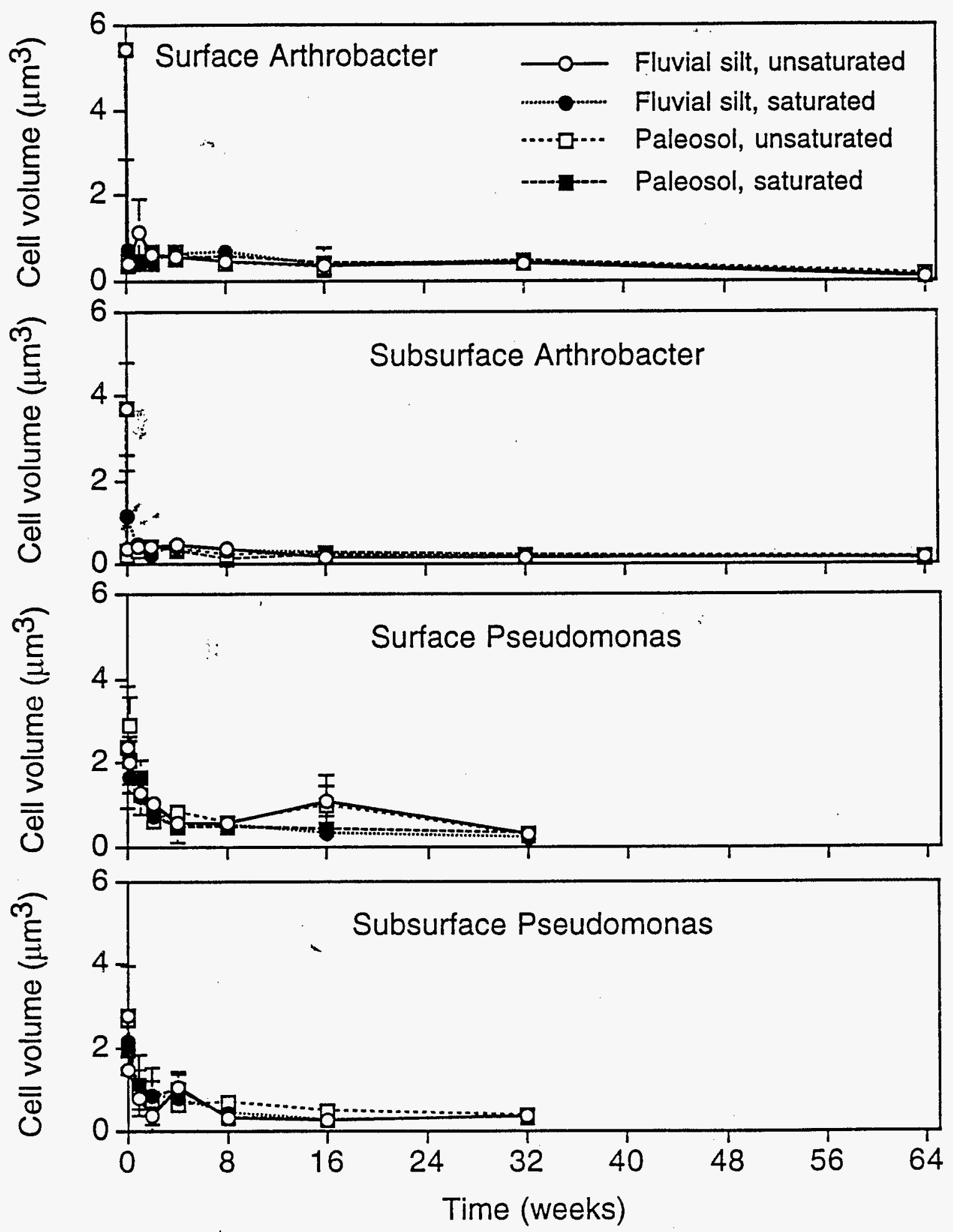

Figure 2. Cell volumes of surface and subsurface bacterial strains incubated in sediment microcosms. Enor bars show one standard deviation. (from reference 21 with permission). 
The Pseudomonas strains initially changed their membrane PLFAs in a pattern previously observed in other starved gram negative bacteria, i.e., increased ratios of saturated to unsaturated fatty acids, increased ratios of trans to cis monoenoic fatty acids, and increased ratios of cyclopropyl fatty acids to their monoenoic precursors (Figs. 3 and 4). 21,23,24 High ratios of these values have been associated with physiological stress, including nutrient deprivation. ${ }^{25}$ After several weeks of incubation in sediment microcosms, some of these ratios began to return to levels approaching those of the original inoculum. This suggests that alteration of membrane fluidity, mediated by changes in membrane PLFAs, is a transient response to starvation conditions and that cells starved for long periods ( $>1$ year) may have membrane PLFA patterns that are very similar to those of unstarved cells. This may also explain the fact that ratios thought to be indicative of physiological stress are rarely seen in samples from deep subsurface environments. 26,27

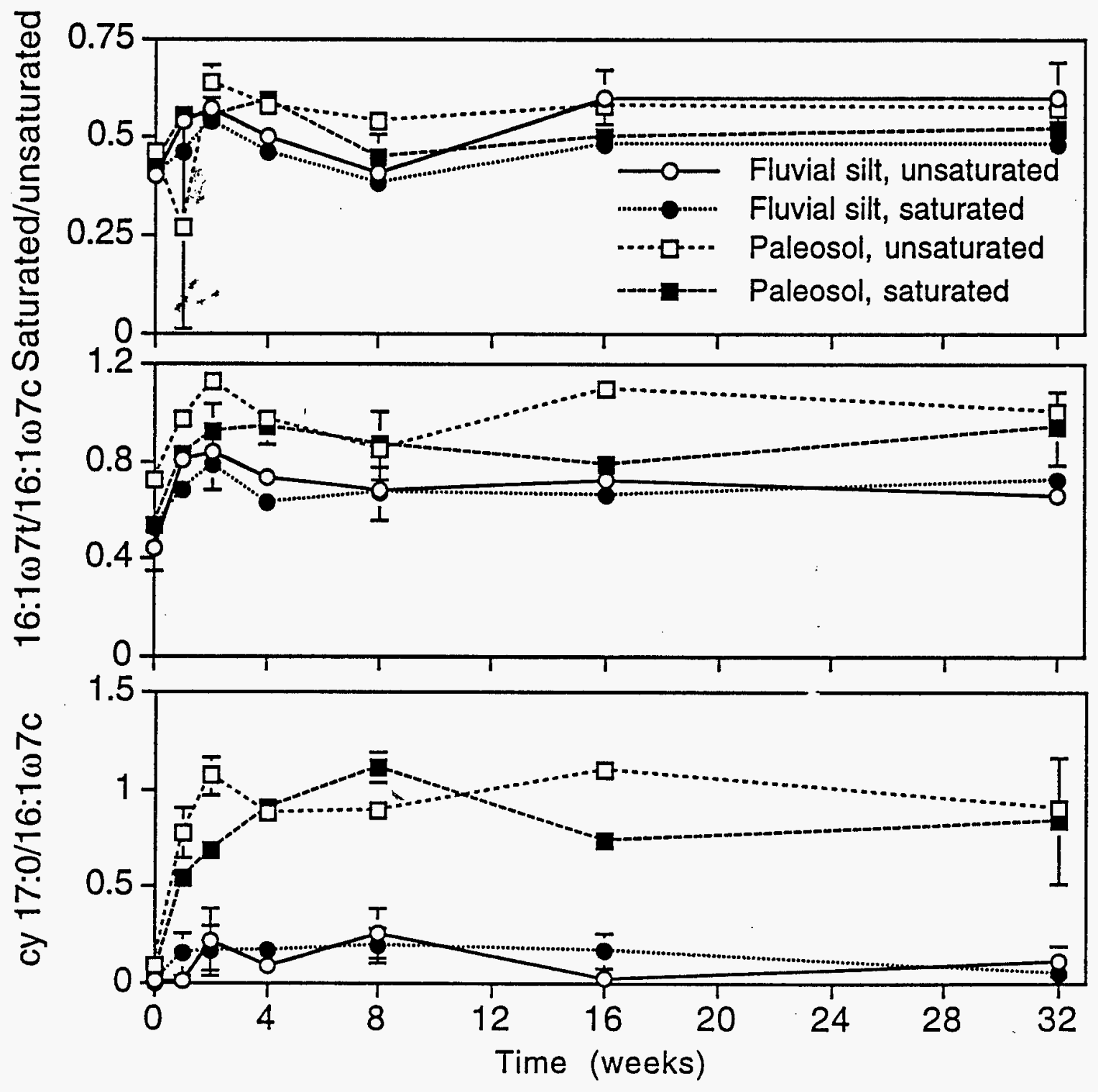

Figure 3. PLFA stress-associated ratios of a subsurface Pseudomonas fluorescens strain in sediment microcosms. Error bars show 1 standard deviation. From reference 21, with permission. 

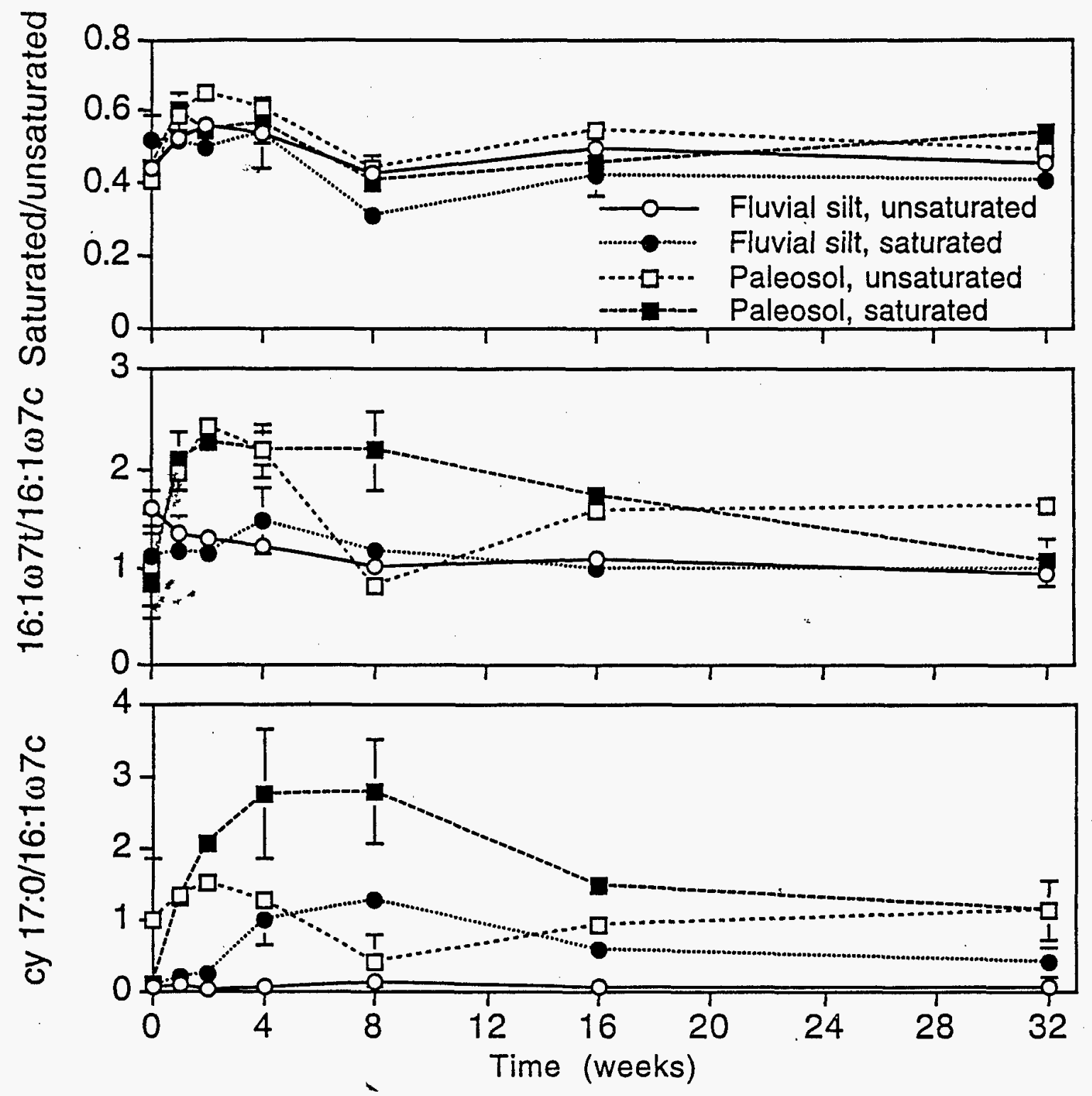

Figure 4. PLFA stress-associated ratios of a surface Pseudomonas fluorescens strain in sediment microcosms. Error bars show 1 standard deviation. From reference 21, with permission.

The Arthrobacter strains showed little indication in their PLFAs of physiological stress during over one year of incubation in the sediment microcosms. Changes in PLFA profiles that would indicate changes in membrane fluidity, e.g., increased ratios of saturated to unsaturated fatty acids, increased PLFA chain lengths, and increased ratios of iso-branched to anteiso-branched fatty acids occurred transiently (within 2 to 4 weeks) if at all. PLFA profiles remain unchanged in these Arthrobacter strains, despite other indications of a physiological response to starvation conditions, e.g., the dwarfing response.

\subsection{FIELD APPROACH}

Our field sampling approach was designed to determine patterns of microbial survival and succession over a geologic time scale and to characterize the physiological status of microbial communities that have been sequestered in the subsurface. For this purpose, we developed the concept of a chronosequence of buried sediments. The idea of the chronosequence was to study a series of buried sediments that vary in the amount of time that they have been buried, but that were deposited under similar geological and climatic conditions. For this purpose, we chose sites in the Palouse area of eastern Washington 
State, an area also known as the Channeled Scablands. Soils and subsurface sediments in this area consist of loess silts deposited on the underlying basalt bedrock over a period of more than 1 million years. Climatic conditions are thought to have remained relatively constant over this period. However, catastrophic glacial flooding occurred several times resulting in the formation of channels in the loess. Soils formed in the loess at the land surface and were then buried by subsequent aeolian silt deposits. These buried soils (paleosols) form a chronosequence of soils, ranging in age from modern to greater than 1 million years.

Sampling sites were near the towns of Washtucna and Winona. Average annual precipitation is $29 \mathrm{~cm}$ at Washtucna and $36 \mathrm{~cm}$ at Winona. The Washtucna site was flooded multiple times during the last glaciation (approximately 13,000 years ago); the Winona site is at a higher elevation and is thought not to have been flooded during this time. We sampled these sediments initially by horizontal drilling and coring at road cuts and more recently by vertical drilling and coring at sites adjacent to road cuts. The sediments are relatively easy to access at the road cuts; however, there is a chance that they have been altered by their proximity to the surface. The vertical borehole sites were chosen to be near enough to the road cuts for the road cuts serve as stratigraphic controls, but far enough away to avoid the altering effects of the road cuts. A hollow-stem agar, split-spoon sampling technique was used. All samples were collected from above the water table and from within the silt loess overlying the basalt bedrock. Fluorescent microbeads were added to the borehole at intervals as particulate tracers to determine whether contaminant microbes could have been introduced into sample material. Samples for miçobiology were collected exclusively from the centers of cores. Tracer beads were not observed in any subcore samples.

Sediment age was determined by thermoluminescence, identification of tephra layers, and by estimated rates of pedogenesis. Additionalky, at the Winona site, a geomagnetic reversal was noted at a depth of $28.3 \mathrm{~m}$, indicating a sediment age of 780,000 years. Recharge was quantified by the chloride mass balance approach. 28 . Chemical analyses included measurement of leachable organic and inorganic carbon. Microbiological analyses included direct microscopic counts, heterotrophic plate counts, measurement of ${ }^{3} \mathrm{H}$-glucose uptake, measurement of ${ }^{14} \mathrm{C}$-glucose mineralization, total PLFA analysis as a measure of biomass, PLFA profiles as indicators of community makeup and physiological state, and use of the Biolog assay as a measure of microbial diversity. The Biolog assay tests the abilities of microorganisms to use 95 different organic compounds as electron donors for microbial metabolism.

$+i$

Sediment ages ranged to approximately 250,000 years at a depth of $15 \mathrm{~m}$ at the Washtucna site and approximately 1 million years at $37 \mathrm{~m}$ in the Winona borehole. Porewater ages ranged from modern at the surface to approximately 3600 years at $15 \mathrm{~m}$ depth at the Washtucna site and approximately 1200 years at $37 \mathrm{~m}$ depth at the Winona site. The younger porewater ages at the Winona site reflect the higher precipitation rate at this site. The sediment ages represent the oldest possible age of the microbial communities; the porewater ages represent the youngest possible age.

Microbial biomass, as indicated by total PLFAs and by direct microscopic counts, declined with depth (and also with sediment and porewater ages) at both sites (Fig. 5). Similar patterns were observed for counts of culturable microorganisms and for rates of radiolabeled glucose uptake and mineralization. While the rates of ${ }^{14} \mathrm{C}$-glucose mineralization to $\mathrm{CO}_{2}$ declined with depth, there was an increase with depth in the lag time until mineralization began. Although the total PLFA data indicate that the magnitude of the biomasses were approximately equal in samples of equivalent sediment age at the two sites, the PLFA profiles indicated that the microbial communities at the two sites differed markedly from each other (Fig. 6). The ratio of diglyceride fatty acids (DGFAs) to PLFAs increased with depth at both sites. DGFAs are thought to indicate the numbers of dead microbial cells, because PLFAs are rapidly dephosphorylated to DGFAs when cells die. ${ }^{25}$ Microbial diversity, as indicated by the Biolog assay, declined with depth at both sites.

Although biomass declined sharply with depth at these sites, there was still detectable biomass and potential metabolic activity in the deepest, oldest samples. Winona samples with sediment ages approaching 1 million years and porewater ages of approximately 1200 years showed evidence of viable biomass. Sediment and porewater ages thus constrain the age of the microbial communities at this depth to $10^{3}$ to $10^{6}$ years. Given that the sediments at the Winona site were not flooded during the last glacial period and thus have remained unsaturated, the transport of microorganisms into deeply buried sediments would occur by unsaturated flow (recharge) from the surface. Balkwill et al. found that microbial transport by unsaturated flow processes was negligible in semi-arid regions of southeastern Washington State. ${ }^{29}$ Bacteria are transported in water films that move by capillary forces in unsaturated flow systems. At low water contents, capillary forces retain water in increasingly smaller pores. Under these conditions, bacterial transport was negligible due to physical filtration and attachment to particle surfaces. ${ }^{29}$ It is more likely, therefore, that the microbial communities at depth are much older than the porewater ages; and they may even be remnants of original surface soil communities. 


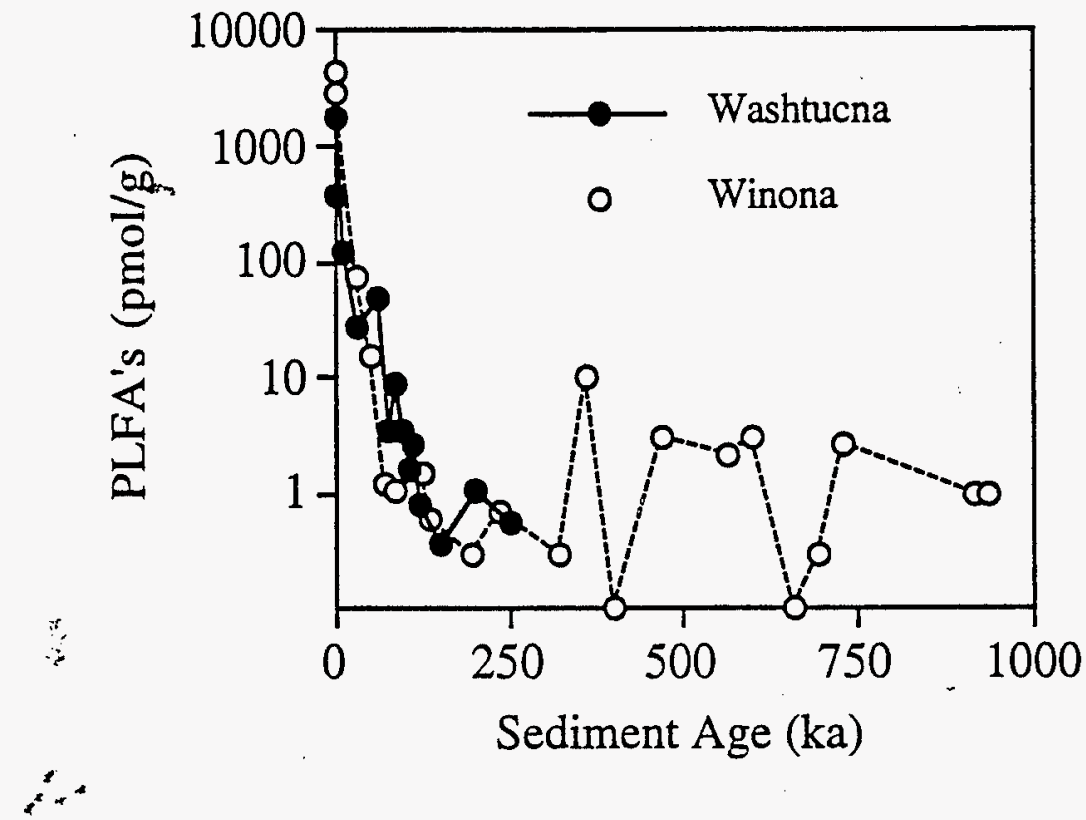

Figure 5. Biomass, as indicated by PLFAs vs. sediment age at two sites in the Palouse region of eastern Washington State.

PLFA profiles indicate changes in the community profiles with depth and sediment age (Fig. 6). If it is true that these subsurface communities represent the survivors from original soil communities, then the patterns with sediment age indicate which microbial groups are capable of persisting for at least 1 million years and which groups declined in biomass or disappeared. The finding of polyunsaturated fatty acids indicative of eukaryotes at depth is surprising, since they have rarely been detected in other deep sediments. These may represent ancient microeukaryotes or ancient plant cell remnants. PLFA signature biomarkers indicative of gram negative bacteria such as Pseudomonas and gram positive bacteria such as Arthrobacter were present in sediments nearly 1 million years old. The differences in community profiles within sediments of similar ages observed in the two boreholes may be the result of spatial heterogeneity in microbial communities or they may be due to differences in moisture patterns (unsaturated recharge and saturation by flooding).

PLFA profiles also give some hint as to the physiological state of the microorganisms. The increase in the ratio of DGFAs to PLFAs indicates that large proportions of the communities in the deepest sediments are dead. These dead cells may provide a small source of nutrients to the survivors; however, physical access to this and other sources of energy and other nutrients is extremely limited in unsaturated sediments. The ratio of cyclopropyl saturated fatty acids to monoenoic unsaturated fatty acids (a stress signature ratio) increased with depth in both boreholes, peaking at a depth corresponding to a sediment age of about 150,000 years in the Winona borehole. This stress ratio then declined as depth increased, reaching values near those of the surface soils at depths corresponding to sediment ages of 500,000 to 1 million years. This corroborates previous stress signature data observed in sediments collected at road cuts...In road cut samples, all three types of stress signature ratios (saturated/unsaturated fatty acids, trans/cis monoenoic fatty acids, and cyclopropyl/monoenoic fatty acids) increased with depth from surface soil samples to buried sediments of intermediate age (10,000 to 100,000 years) and then decreased as depth increased further. Stress signature ratios in the deepest sediments, whose ages were approximately 1 million years, were approximately equal to those of the surface soils.

\subsection{SUMMARY AND CONCLUSIONS}

Laboratory and field studies support the idea that microorganisms in some subsurface environments are capable of persisting with little input of new energy sources and thus with few opportunities for reproduction over periods of time ranging from decades to perhaps as long as millions of years. Laboratory experiments alone cannot prove microbial survival for geologic time periods. However, they do provide supporting data. The experiments described here show that subsurface bacteria are capable of survival in high numbers for at least a year. If the cells had died out completely within a year, then serious doubt would have been cast on the notion of survival in situ for geologic time periods. The laboratory microcosm data also show that environmental parameters such as sediment type and moisture content exert strong influences on 

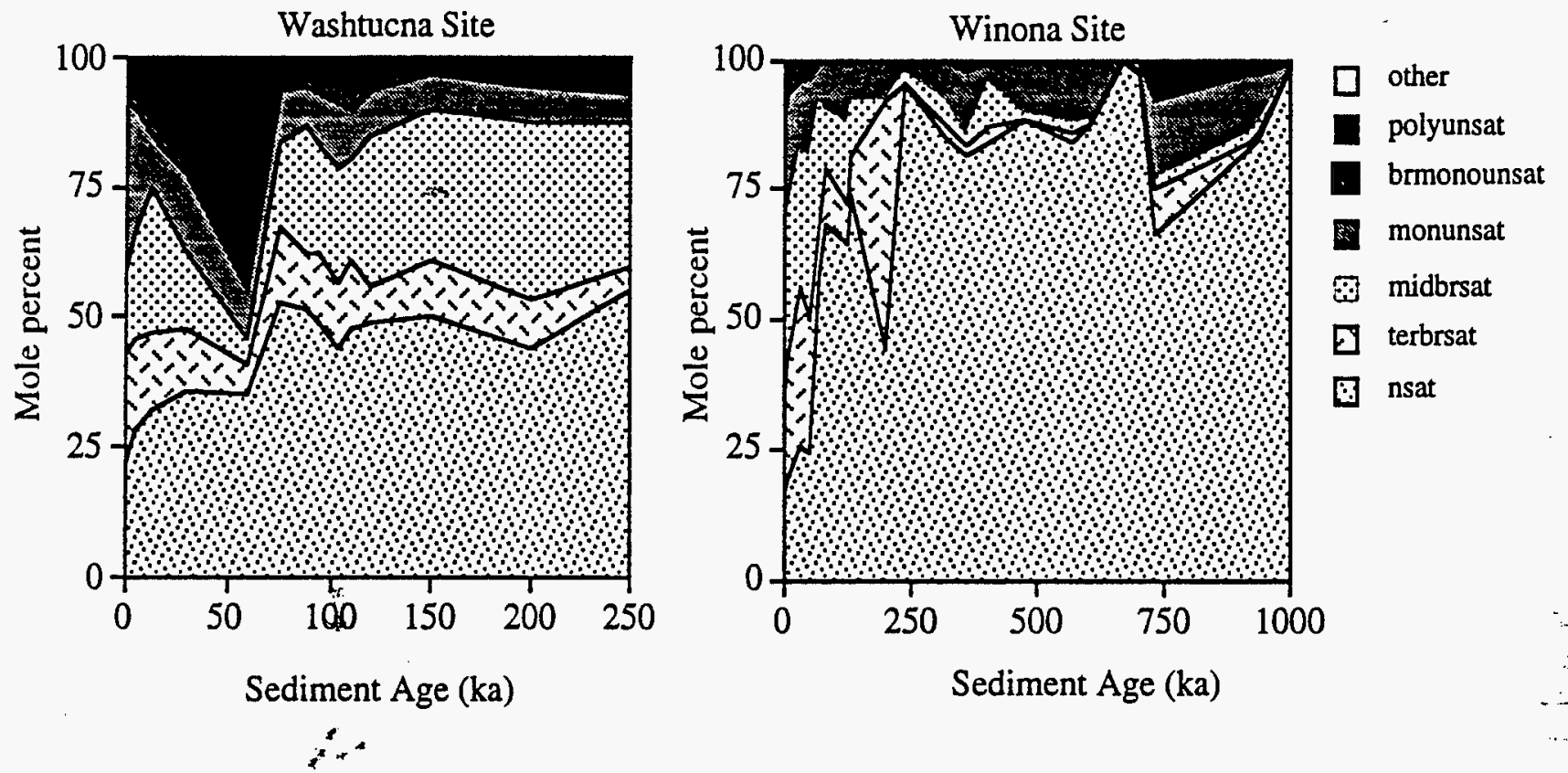

Figure 6. Mole percents of signature PLFA classes (representing different functional groups of microorganisms) vs. sediment age at two sites in the Palouse region of eastern Washington State. Polyunsaturated PLFA (polyunsat) for micro-eukaryotes; branched monounsaturated PLFA (brmonounsat) for gram hegative bacteria including reducing organisms such as sulfate reducing and iron reducing bacteria; normal monounsaturated PLFA (monounsat) for typical gram negative bacteria such as Pseudomonas; mid-chain branched saturated PLFA (midbrsat) for gram variable organisms such as the actinomycetes; terminaily branched saturated PIFA for typical gram positive bacteria such as Arthrobacter; normal saturated PLFA (nsat) which are ubiquitous and not indicative of any single group of microorganisms.

microbial survival. It is easy to imagine that conditions exist in some subsurface environments that are even more conducive to microbial survival that than those of our microcosms. The cell size data of our experiments shed further light on the role of cell miniaturization in subsurface environments. The bacteria in our experiments underwent rapid downsizing as an initial response to nutrient deprivation and then slowed their rates of miniaturization to nearly undetectable levels. This slowdown in the rate of miniaturization occurred well before the cells reached the status of ultramicrobacteria. By slowing their rates of miniaturization, and presumably slowing their rates of endogenous metabolism, they may be able sustain life through very modest expenditure of cellular reserves. They may not reach the lower size limits for life $(0.1$ to 0.2 $\mu \mathrm{m}$ diameter?) until they have been sequestered In situ for decades or more.

The finding that subsurface bacteria are not significantly better adapted for long-term survival than their surface counterparts is perhaps not entirely surprising. The subsurface bacteria that have been isolated to date are generally not radically different from surface bacteria in their physiologies. Though novel species have been identified in subsurface samples, the majority are phylogenetically related to previously described surface isolates. Thus, the subsurface appears not to have exerted sufficient selective pressure to generate radically different physiological types. Most surface environments (soils and aquatic environments) also select for starvation survival. It should also be noted that when viewed on a geologic time scale, subsurface bacteria are not permanently separated from surface environments. The normal movements of ground water and rocks constantly recycles subsurface materials including microorganisms to the subsurface. ${ }^{30}$ Thus, bacteria may not be sequestered in the subsurface for time intervals that are long enough for selection of truly novel bacterial types. Another possibility is that the strains that we have tested are already optimally selected for starvation survival, i.e., they have reached energetically constrained limits.

The field data further demonstrate the survival capabilities of microorganisms in the subsurface. The porewater age data and the sediment age data constrain our estimates of the age of the microbial communities. For the deepest sediments, the age constraints are 1200 years and 1 million years. However, the fact that these sediments are unsarurated indicates that microbial transport of colonizing bacteria from the surface to deep sediments may be minimal, so the majority of the 
microorganisms in the subsurface are likely populations that have persisted since the time of burial. The unsaturated nature of these sediments and the low concentrations of organic carbon suggest that microbial persistence has come about through long-term survival, rather than active metabolism and continuous cellular reproduction. Phelps estimated cell generation times of greater than 100 years for coastal plain sediment aquifers in the southeastern United States. ${ }^{12}$ Nutrient fluxes in unsaturated sediments with low recharge rates are probably orders of magnitude lower than in coastal plain sediments. Rates of metabolic activity have been estimated to be 4 orders of magnitude or more lower in deep vadose zones than in aquifer sediments. ${ }^{12}$ Therefore, average in situ generation times in deep vadose zones of arid and semiarid regions such as those in our study might best be estimated in millennia. Clearly, the microorganisms of these vadose zone sediments are extremely well adapted for long-term starvation survival.

Long-term survival of microorganisms in a relatively inactive state within sediments and rocks in subsurface terrestrial environments has implications for the consideration of life in extraterrestrial rocks and sediments. As challenging and inhospitable as the deep biosphere is on Earth, it can only be worse in extraterrestrial subsurface environments. Nutrient deprivation as well as temperature extremes, moisture stress, and other environmental hardships likely prevail in extraterrestrial subsurface environs. In looking for life, past or present, on other planets, the familiar detection-limit problems in our assays are challenging. Cells, if they exist, are likely dead or inactive, and extremely small. Indeed, putative nanobacterial fossils in McKay et al's report of past life on Mars $^{31}$ have analogous forms on Earth. ${ }^{32}$ Whether such forms are truly cellular is opep for debate; their extremely small size is less than that of the ultramicrobacteria found in terrestrial environments. 18 Even if viable cells exist in extraterrestrial rocks or sediments, detecting their activity will be an even greater challenge than it is on Earth. In situ subsurface microbial activities on Earth are generally detectable only by biogeochemical modeling based on biologically mediated chemical change along a groundwater flow path or in porewaters that are moving by diffusion. It may be necessary to employ the same approach in searching for life on other planets, rather than hoping to design instruments sensitive enough to detect microbial activities in extraterrestrial rocks or sediments. For subsurface scientists, it is extremely gratifying that the consideration of extraterrestrial life has intensified interest in terrestrial deep subsurface environments. Regardless of whether or not Earth's deep biosphere is an appropriate analog for the extreme conditions that exist in extraterrestrial systems, it stretches our concepts of the limits for life.

\section{ACKNOWLEDGMENTS}

Research described in this paper was supported by the Deep Microbiology Subprogram of the Subsurface Science Program, Office of Energy Research, U. S. Department of Energy (Grant no. DE-FG03-93ER-61683).

\section{REFERENCES}

1. D. L. Balkwill, "Numbers, diversity, and morphological characteristics of aerobic, chemoheterotrophic bacteria in deep subsurface sediments from a site in South Carolina", Geomicrobiol. J. 7, pp. 33-52, 1989.

2. D. R. Boone, Y. Liu, Z.-J. Zhao, D. L. Balkwill, G. R. Drake, T. O. Stevens, and H. C. Aldrich. "Bacillus infernus sp. nov., an Fe(III)- and Mn(IV)-reducing anaerobe from a deep terrestrial subsurface", Int. J. System. Bacteriol. 45, pp. 441-448, 1995.

3. J. K. Fredrickson, and T. C. Onstott, "Microbes deep inside the earth", Sci. Amer. 275, pp. 68-73, October 1996.

4. F. J. Brockman, T. L. Kieft, J. K. Fredrickson, B. N. Bjornstad, S. W. Li, W. Spangenburg, and P. E. Long, "Microbiology of vadose zone paleosols in southcentral Washington State", Microb. Ecol. 23, pp. 279-301, 1992.

5. D. L. Haldeman, D. L., and P. S. Amy, "Characterization of the microbiology within a $21 \mathrm{~m}^{3}$ section of rock from the deep subsurface", Microb. Ecol. 26, pp. 145-159, 1993.

6. T. L. Kieft, P. S. Amy, F. J. Brockman, J. K. Fredrickson, B. N. Bjornstad, and L. L. Rosacker, "Microbial abundance and activities in relation to water potential in the vadose zone of arid and semiarid sites", Microb. Ecol.26, pp. 59-78, 1993.

7. T. L. Kieft, J. K. Fredrickson, J. P. McKinley, Bjornstad, B. N., S. A. Rawson, T. J. Phelps, F. J., Brockman, and S. M. Pfiffner, "Microbiological comparisons within and across contiguous lacustrine, paleosol, and fluvial subsurface sediments", Appl. Environ. Microbiol. 61, pp. 749-757, 1995.

8. E. M. Murphy, J. A. Schramke, J. K. Fredrickson, H. W. Bledsoe, A. J. Francis, D. S. Sklarew, and J. C. Linehan, "The influence of microbial activity and sedimentary organic carbon on the isotope geochemistry of the Middendorf aquifer", Water Resour. Res. 28, pp. 723-740, 1992.

9. T. J. Phelps, S. M. Pfiffner, K. A. Sargent, and D. C. White, "Factors influencing the abundance and metabolic capacities of microorganisms in eastern coastal plain sediments", Microb. Ecol. 28, pp. 351-364, 1994.

10. J. K. Fredrickson, J. P. McKinley, S. A. Nierzwicki-Bauer, D. C. White, D. B. Ringelberg, S. A. Rawson, S.-M. Li, F. J. Brockman, and B. N. Bjornstad, "Microbial community structure and biogeochemistry of Miocene 
subsurface sediments: implications for long-term microbial survival", Molec. Ecol. 4, pp. 619-626, 1995.

11. F. H. Chapelle, and D. R. Lovley, "Rates of microbial metabolism in deep coastal aquifers", Appl. Environ. Microbiol. 56, pp. 1865-1874, 1990.

12. T. J. Phelps, E. M. Murphy, S. M. Pfiffner, and D. C. White, "Comparison b̀tween geochemical and biological estimates of subsurface microbial activities", Microb. Ecol. 28, pp. 335-349, 1994.

13. T. L. Kieft, and T. J. Phelps, "Life in the slow lane: activities of microorganisms in the subsurface," The Microbiology of the Terrestrial Subsurface, P. S. Amy, and D. L. Haldeman(Eds.), pp. 137-163, CRC Press, Boca Raton, 1997.

14. J. K. Fredrickson, J. P. McKinley, B. N. Bjornstad, P. E. Long, D. B. Ringelberg, D. C. White, L. R. Krumholz, J. M. Suflita, F. S. Colwell, R. M. Lehman, T. J. Phelps, T. C. Onstott, "Pore-size constraints on the activity and survival of subsurface bacteria in a late Cretaceous shale-sandstone sequence, northwestern New Mexico", Geomicrobiol. J. (In Press).

15. R. Y. Morita, "The starvation-survival state of microorganisms in nature and its relationship to the bioavailable energy", Experientia 46, pp. 813-817, 1990.

16. M. J. Kennedy, S. L. Reader, and L. M. Swierczynski, "Preservation records of micro-organisms: evidence of the tenacity of life", Microbiol. 140, pp. 2513-2529, 1994.

17. R. J. Cano, and M. K. Borucki, "Revival and identification of bacterial spores in 25- to 40-million-year-old Dominican amber", wcience 268, pp. 1060-1064, 1995.

18. T. L. Kieft, "Dwarf cells in soil and subsurface terrestrial environments", Non-Culturable Microorganisms in the Environment, R. R. Colwell, and D. J. Grimes (Eds.), Chapman \& Hall, New York. (In press).

19. P. S. Amy, C. Durham, D. Hall, and D. L. Haldeman. "Starvation-survival of deep subsurface isolates", Curr. Microbiol. 26, pp. 345-352, 1993.

20. T. L. Kieft, D. B." Ringelberg, and D. C. White, "Changes in ester-linked phospholipid fatty acid profiles of subsurface bacteria during starvation and desiccation in porous medium", Appl. Environ. Microbiol. 60, pp. 3292 $3299,1994$.

21. T. L. Kieft, E. Wilch, K. O'Connor, D. B. Ringelberg, and C. C. White, "Survival and phospholipid fatty acid profiles of surface and subsurface bacteria in natural sediment microcosms", Appl. Environ. Microbiol. 63, pp. 1531$1542,1997$.

22. C. W. Boylen, and J. C. Ensign, "Long-term starvation survival of rod and spherical cells of Arthrobacter crystallopoietes", J. Bacteriol. 103, pp. 569-577, 1970.

23. J. B. Guckert, M. A. Hood, and D. C. White, "Phospholipid ester-linked fatty acid profile changes during nutrient deprivation of Vibrio cholerae: increases in the trans/cis ratio and proportions of cyclopropyl fatty acids", Appl. Environ. Microbiol. 52, pp. 794-801, 1986.

24. S. A. Rice, and J. D. Oliver, "Starvation response of the marine barophile CNPT-3", Appl. Environ. Microbiol. 58, pp. 2432-2437, 1992.

25. D. C. White, "Is there anything else you need to understand about the microbiota that cannot be derived from analysis of nucleic acids?", Microb. Ecol. 28, pp. 163-166, 1994.

26. G. A. Smith, J. S. Nickels, B. D. Kerger, J. D. Davis, S. P. Collins, J. T. Wilson, J. F. McNabb, and D. C. White, "Quantitative characterization of microbial biomass and community structure in subsurface material: a prokaryotic consortium responsive to organic contamination", Can. J. Microbiol. 32, pp. 104-111, 1986.

27. T. J. Phelps, D. Ringelberg, D. Hedrick, J. Davis, C. B. Fliermans and D. C. White, "Microbial biomass and activities associated with subsurface environments contaminated with chlorinated hydrocarbons", Geomicrobiol.J. 6, pp. 157-170, 1988.

28. E. M. Murphy, T. R. Ginn, and J. L. Phillips, "Geochemical estimates of paleorecharge in the Pasco Basin: evaluation of the chloride mass-balance technique', Water Resour. Res. 32, pp. 2853-2868, 1996.

29. D. L. Balkwill, E. M. Murphy, D. M. Fair, D. B. Ringelberg, and D. C. White, "Microbial communities in high and low recharge environments: implications for microbial transport in the vadose zone", Microb. Ecol. (In press).

30. T. O. Stevens,"Subsurface microbiology and the evolution of the biosphere", The Microbiology of the Terrestrial Subsurface, P. S. Amy, and D. L. Haldeman (Eds.), pp. 205-223, CRC Press, Boca Raton, 1997.

31. D. S. McKay, E. K. Gibson, K. L. Thomas-Keprta, H. Vali, C. S. Romanek, S. J. Clemett, X. D. F. Chillier, C. R. Maechling, R. N. Zare, "Search for past life on Mars: Possible relic biogenic activity in Martian meteorite ALH84001", Science 273, 924-930, 1996.

32. R. L. Folk, "SEM imaging of bacteria and nannobacteria in carbonate sediments and rocks", J. Sediment. Petrol. 5, pp. 990-999, 1993.

Further author information -

T.L.K.(correspondence): Email: tkieft@nmt.edu; Telephone:505-835-5321; FAX: 505-835-5668

-The submitted manuscript has been authorized by a contractor of the U.S. Govemment under contract No. DE-AC05-960R22464. Accordingly, the U.S

Government retains a non-exclusive, royalty-free license to publish or reproduce the published form of this contribution, or allow others to do so. for U.S. 
M98001915

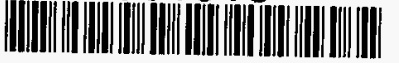

Report Number (14) $\frac{O R N L / C P--95437}{\operatorname{CONF}-970706}$

Publ. Date (11) 199709

sponsor Code (18) DOE, XF

JC Category (19) $4 C-900, D O E / E R$

DOE 